\title{
Kemampuan koneksi matematik siswa dalam menyelesaikan soal investigasi matematika
}

\author{
Ade Irawan ${ }^{*}$, Sri Subarinah ${ }^{2}$, Arjudin $^{3}$, Sudi Prayitno $^{4}$ \\ ${ }^{1}$ Mahasiswa Pendidikan Matematika, FKIP, Universitas Mataram, Mataram \\ ${ }^{2}$ Dosen Pendidikan Matematika, FKIP, Universitas Mataram, Mataram \\ ${ }_{3}^{3}$ Dosen Pendidikan Matematika, FKIP, Universitas Mataram, Mataram \\ irawanade1515@gmail.com
}

Diterima: 20-09-2021; Direvisi: 26-09-2021; Dipublikasi: 30-09-2021

\begin{abstract}
This study aims to determine and describe the level of mathematical connection ability of students in solving mathematical investigation questions in grade VII students at SMPN 2 Labuapi in the academic year 2020/2021. This type of research is descriptive qualitative research. The subjects in this study were 10 students of VII A class at SMPN 2 Labuapi. The data was collected in the form of test results of students' mathematical connection skills in solving mathematical investigation questions at triangles and quadrangle matter and the results of interviews. The test results were analyzed according to the indicators of students' mathematical connection ability, which is being able to connect the mathematical concepts that have been studied and those being studied and to connect the mathematical concepts to everyday life. Based on the results of data analysis, that the mathematical connection ability of students in solving mathematical investigation questions was still in the sufficient category. Overall there were 3 students (30\%) in very poor category, 2 students (20\%) in very good category, 2 students (20\%) in good category, 2 students (20\%) in good enough category, and 1 student $(10 \%)$ in poor category.
\end{abstract}

Keywords: mathematical connection skills; investigation questions; triangles; quadrangle

\begin{abstract}
Abstrak
Penelitian ini bertujuan untuk mengetahui dan mendeskripsikan kemampuan koneksi matematik siswa dalam menyelesaikan soal investigasi matematika pada siswa kelas VII di SMPN 2 Labuapi tahun pelajaran 2020/2021. Jenis penelitian ini adalah penelitian kualitatif deskriptif. Subjek dalam penelitian ini adalah 10 orang siswa kelas VII A SMPN 2 Labuapi tahun pelajaran 2020/2021. Data yang dikumpulkan berupa hasil tes kemampuan koneksi matematik siswa dalam menyelesaikan soal investigasi matematika pada materi segitiga dan segiempat dan hasil wawancara. Hasil tes dianalisis sesuai dengan indikator kemampuan koneksi matematik siswa, yaitu mampu menghubungkan antara konsep matematika yang sudah dipelajari dengan yang sedang dipelajari dan menghubungkan antara konsep matematika dengan kehidupan sehari-hari. Berdasarkan hasil analisis data, diperoleh bahwa kemampuan koneksi matematik siswa dalam menyelesaikan soal investigasi matematika pada materi segitiga dan segiempat masih dalam kategori cukup. Secara keseluruhan siswa yang termasuk dalam kategori kategori sangat baik sebanyak 2 siswa (20\%), kategori baik sebanyak 2 siswa (20\%), karegori cukup sebanyak 2 siswa (20\%), kategori kurang sebanyak 1 siswa (10\%), dan sangat kurang sebanyak 3 siswa (30\%).
\end{abstract}

Kata Kunci: kemampuan koneksi matematik; soal investigasi; segitiga; segiempat

\section{PENDAHULUAN}

Menurut Undang-undang Sistem Pendidikan Nasional Nomor 20 Tahun 2003 menyatakan bahwa pendidikan adalah usaha sadar dan terencana untuk mewujudkan suasana belajar dan proses pembelajaran agar peserta didik secara aktif 
mengembangkan potensi dirinya untuk memiliki kekuatan spiritual keagamaan, pengendalian diri, kepribadian, kecerdasan, akhlak mulia, serta keterampilan yang diperlukan dirinya, keluarga, masyarakat, bangsa dan negara (Suhana, 2014).

Berdasarkan hasil observasi peneliti selama melaksanakan Program Pengalaman Lapangan (PPL) di kelas VII SMPN 2 Labuapi menunjukkan bahwa terdapat permasalahan yang sering dihadapi dalam melaksanakan kegiatan pembelajaran. Salah satunya adalah siswa yang belum mampu dalam menyelesaikan masalah matematika, terlebih lagi jika diberikan soal-soal yang mempunyai keterhubungan dengan materi lain ataupun soal-soal yang berhubungan dengan kehidupan sehari-hari. Kondisi tersebut dikarenakan oleh beberapa hal yaitu soal-soal pemecahan masalah yang biasa diberikan guru adalah soal-soal rutin yang dalam penyelesaiannya hanya terpaku pada prosedur yang diajarakan. Hal ini sejalan dengan yang dinyatakan oleh Tandilling (2012) bahwa tidak dapat dipungkiri sebagian besar guru matematika jarang memberikan soal-soal matematika kepada siswanya dalam bentuk non-rutin.

Investigasi matematika merupakan kegiatan yang penting untuk meningkatkan keterampilan pemecahan masalah dan bermanfaat bagi siswa dalam mengembangkan kemampuan berpikirnya secara optimal (Subarinah et al., 2018) dikarenakan pada tahapan investigasi matematika, siswa akan mengembangkan pemikirannya secara kreatif, analitik, simetrik, dan kritis (Subarinah et al., 2020) serta rasa ingin tahu, berani bertanya dan percaya diri (Subarinah, 2016). Istilah investigasi dalam pembelajaran matematika pertama kali direkomendasikan oleh Committee of Inquiry into the Teaching of Mathematics in School dalam laporan Cockroft (Subarinah et al., 2018). Dalam laporan tersebut dinyatakan bahwa pembelajaran matematika dalam setiap jenjang pendidikan harus meliputi: eksposisi (pemaparan), diskusi, kerja praktek, pemantapan dan latihan, pemecahan masalah, dan kegiatan investigasi (Lidinillah, 2009)

NCTM (2000) menetapkan bahwa terdapat lima kemampuan yang perlu dimiliki oleh siswa melalui pembelajaran matematika yang tercakup dalam standar proses yaitu pemecahan masalah (problem solving), penalaran dan pembuktian (reasoning and proof), koneksi (connection), komunikasi (communication), dan representasi (representation). Dari lima kemampuan di atas, pengembangan kemampuan koneksi matematik menjadi salah satu fokus perhatian pada penelitian ini. Kemampuan koneksi matematis diperlukan sejak dini melalui pembelajaran di kelas agar siswa mampu memecahkan masalah dan mengaplikasikan konsep matematika sebagai salah satu bekal hidupnya di masa sekarang dan masa yang akan datang.

Koneksi matematika adalah kemampuan untuk mengaitkan konsep-konsep matematika, baik antar konsep matematika itu sendiri maupun mengaitkan konsep matematika dengan bidang lain (Lestari, 2014). Hal ini sejalan dengan yang dikemukakan oleh Solihatin (2012) yang menyatakan bahwa koneksi adalah suatu cara untuk mengaitkan satu pokok bahasan yang ditinjau secara terpisah dari sudut yang 
berbeda tetapi mempunyai keterhubungan satu dengan yang lainnya. Menurut NCTM (2000) terdapat tiga indikator kemampuan koneksi matematika yaitu menghubungkan antara konsep matematika yang sudah dipelajari dengan yang sedang dipelajari, menghubungkan antara konsep matematika dengan bidang lain, dan menghubungkan antara konsep matematika dengan kehidupan sehari-hari.

Berdasarkan uraian di atas, maka peneliti tertarik untuk melakukan penelitian ini yang bertujuan untuk mengetahui tingkat kemampuan koneksi matematik siswa dalam menyelesaikan soal investigasi matematika kelas VII SMPN 2 Labuapi tahun pelajaran 2020/2021 pada materi segitiga dan segiempat.

\section{METODE PENELITIAN}

Jenis penelitian yang digunakan dalam penelitian ini adalah penelitian kualitatif deskriptif sedangkan subjek dalam penelitian ini adalah 10 siswa kelas VII A di SMPN 2 Labuapi Tahun Pelajaran 2020/2021 yang dipilih oleh guru matematika berdasarkan penyelesaian masalah yang dilakukan dan kemampuan subjek dalam berkomunikasi. Sumber data dalam penelitian ini ada dua, yaitu data primer dan data sekunder. Data primer adalah data yang diperoleh secara langsung dari informan atau objek yang akan diteliti. Sedangkan data sekunder adalah data yang diperoleh dari teknik pengumpulan data yang menunjang data primer.

Metode pengumpulan data yang digunakan dalam penelitian ini adalah sebagai berikut.

\section{Metode Dokumentasi}

Dokumentasi dalam penelitian ini digunakan untuk memperoleh data tentang daftar nama, jumlah peserta didik, dan data lain yang akan digunakan untuk kepentingan penelitian. Metode dokumentasi digunakan untuk mengumpulkan data subjek dan jumlah siswa yang menjadi subjek penelitian.

\section{Metode Tes}

Tes merupakan suatu cara yang digunakan untuk melaksanakan kegiatan pengukuran, yang di dalamnya terdapat serangkaian pertanyaan-pertanyaan atau latihan yang digunakan untuk mengukur keterampilan, pengetahuan, kecerdasan, kemampuan, dan bakat yang dimiliki oleh seseorang atau kelompok (Prayitno, 2019).Tes digunakan untuk mengetahui kemampuan siswa dalam menyelesaikan masalah investigasi.

\section{Metode Wawancara}

Dalam penelitian ini, Wawancara adalah salah satu cara untuk mengumpulkan data melalui tanya-jawab dengan responden secara langsung atau dengan perantara yang mengetahui masalah (objek) yang akan diteliti (Rozak, 2012).Wawancara dilakukan untuk mengetahui bagaimana proses koneksi siswa dalam menyelesaikan masalah investigasi yang belum dapat dilihat secara jelas melalui tes. 
Instrumen yang digunakan dalam penelitian ini adalah tes kemampuan koneksi matematika siswa yang disusun berdasarkan indikator soal investigasi matematika yang sebelumnya telah diuji validitas dan reliabilitasnya. indikator soal investigasi matematika dapat dilihat pada tabel 1 berikut.

Tabel 1. Indikator Soal Investigasi Matematika

\begin{tabular}{cl}
\hline No. & \multicolumn{1}{c}{ Indikator } \\
\hline 1 & Siswa dapat menemukan solusi penyelesaian dengan menggunakan beberapa metode \\
& penyelesaian. \\
2 & Siswa dapat melakukan banyak kegiatan matematis (doing mathematics). \\
3 & $\begin{array}{l}\text { Siswa dapat menggunakan idenya tanpa harus berfokus pada hasil sehingga siswa } \\
\text { mampu memecahkan masalah dengan beberapa metode yang berbeda. }\end{array}$ \\
\hline
\end{tabular}

Data yang terkumpul kemudian akan dianalisis secara kuantitatif menggunakan analisis statistik deskriptif dan dianalisis secara kualitatif dengan proses reduksi data, penyajian data, dan penarikan kesimpulan (Ahmad \& Nasution, 2018).

Pengelompokkan kategori kemampuan koneksi matematik siswa dikelompokkan menjadi lima kategori yaitu kategori sangat baik, kategori baik, kategori cukup, kategori kurang, dan kategori sangat kurang. Kategori skor tes siswa menggunakan pengkategorian dengan skala lima pada tabel berikut (Arikunto, 2013).

Tabel 2. Tingkat Kemampuan Koneksi Matematik Siswa

\begin{tabular}{cc}
\hline Rentang Skor Tes Kemampuan Koneksi Matematis & Kategori \\
\hline $85<$ skor $\leq 100$ & Baik Sekali \\
$70<$ skor $\leq 85$ & Baik \\
$59<$ skor $\leq 70$ & Cukup \\
$44<$ skor $\leq 59$ & Kurang \\
$0 \leq$ skor $\leq 44$ & Sangat Kurang \\
\hline
\end{tabular}

\section{HASIL DAN PEMBAHASAN}

Berdasarkan analisis tes kemampuan koneksi matematik dalam menyelesaikan soal investigasi matematika pada materi segitiga dan segiempat yang telah dilakukan, diperoleh nilai rata-rata tingkat kemampuan koneksi matematik siswa kelas VII SMPN 2 Labuapi tahun pelajaran 2020/2021 sebesar 61,70\% dengan kriteria cukup.

Tabel 3. Tingkat Kemampuan Koneksi Matematik Siswa

\begin{tabular}{ccccc}
\hline No. & Nilai & $\begin{array}{c}\text { Tingkat } \\
\text { Kemampuan }\end{array}$ & Banyak Siswa & Persentase \\
\hline 1 & $85<X \leq 100$ & Sangat Baik & 2 & $20 \%$ \\
2 & $70 \leq X \leq 85$ & Baik & 2 & $20 \%$ \\
3 & $59<X \leq 70$ & Cukup & 2 & $20 \%$ \\
4 & $44<X \leq 59$ & Kurang & 1 & $10 \%$ \\
5 & $0 \leq X \leq 44$ & Sangat Kurang & 3 & $30 \%$ \\
\hline
\end{tabular}


Tabel 3 menunjukkan bahwa tingkat kemampuan koneksi matematik siswa dalam menyelesaikan soal investigasi matematika sebagian besar berada pada kategori sangat kurang yaitu sebesar 30\%, sedangkan untuk yang berkemampuan sangat baik, baik, serta cukup hanya sebesar 20\%, dan yang berkemampuan kurang hanya sebesar $10 \%$. Berdasarkan analisis tes kemampuan koneksi matematik pada soal investigasi yang telah dilakukan, diperoleh nilai rata-rata tingkat kemampuan koneksi matematik siswa kelas VII di SMPN 2 Labuapi tahun pelajaran 2020/2021 sebesar 61,7\% atau dengan kriteria cukup. Berikut adalah kriteria dari masing-masing kategori siswa

Tabel 4. Kriteria Kemampuan Koneksi Matematik Siswa pada Tiap Kategori

\begin{tabular}{ll}
\hline Kategori & Kriteria \\
\hline Sangat Baik & Siswa mampu menguasai kedua indikator koneksi matematik yaitu \\
& mampu menghubungkan ide-ide dalam matematika dan menghubungkan \\
antara konsep matematika dengan kehidupan sehari-hari & Siswa mampu menguasai paling sedikit salah satu indikator baik yaitu \\
& menghubungkan ide-ide dalam matematika ataupun menghubungkan \\
& antara konsep matematika dengan kehidupan sehari-hari dan dapat \\
& menyelesaian masalah \\
Cukup & Siswa hanya mampu menguasai salah satu indikator kemampuan koneksi \\
& matematik saja, baik itu menghubungkan ide-ide dalam matematika \\
& ataupun menghubungkan antara konsep matematika dengan kehidupan \\
& sehari-hari dan siswa masih kesulitan dalam mekalukan penyelesaian \\
& masalah \\
& Siswa belum mampu menguasai kedua indikator koneksi matematik yaitu \\
& menghubungkan ide-ide dalam matematika dan menghubungkan antara \\
konsep matematika dengan kehidupan sehari-hari, akan tetapi siswa & dapat melakukan penyelesaian masalah walaupun belum tepat \\
& Siswa tidak mampu menguasai kedua indikator koneksi matematik yaitu \\
& menghubungkan ide-ide dalam matematika ataupun menghubungkan \\
& antara konsep matematika dengan kehidupan sehari-hari dan tidak dapat \\
melakuan penyelesaian masalah
\end{tabular}

\subsection{Kemampuan Koneksi Matematik Siswa Berkemampuan Sangat Baik}

Hasil belajar pada setiap subjek berbeda-beda, Hal ini dilihat juga dari hasil analisis tes kemampuan koneksi matematik yang telah dikerjakan oleh masing-masing subjek pada indikator kemampuan koneksi matematik secara tertulis. Hal tersebut ditunjukkan dari persentase hasil pekerjaan siswa dan skor rata-rata siswa pada indikator menghubungkan antara konsep dalam matematika dan menghubungkan antara konsep matematika dengan kehidupan sehari-hari yaitu masing-masing sebesar $81,82 \%$ dan 97,78\% dengan masing-masing kualifikasi sangat baik. Pada subjek $\mathrm{S}_{\mathrm{SB}} / \mathrm{S}_{09}$ dan $\mathrm{S}_{\mathrm{sB}} / \mathrm{S}_{10}$, dari kedua indikator kemampuan koneksi matematik semua masuk ke dalam kategori sangat baik yang meliputi kemampuan menghubungkan antara konsep dalam matematika dan menghubungkan antara konsep matematika dengan kehidupan seharihari. Hal ini sesuai dengan hasil penelitian yang dilakukan oleh Anandita (2015) bahwa siswa yang mempunyai kemampuan koneksi matematik sangat baik dapat memenuhi semua indikator koneksi dengan baik. 


\subsection{Kemampuan Koneksi Matematik Siswa Berkemampuan Baik}

Hasil belajar pada setiap subjek berbeda-beda, hal ini dilihat juga dari hasil analisis tes kemampuan koneksi matematik yang telah dikerjakan oleh masing-masing subjek pada masing-masing indikator kemampuan koneksi matematik secara tertulis. Hal tersebut ditunjukkan dari persentase hasil pekerjaan siswa dan skor rata-rata siswa pada indikator menghubungkan antara konsep dalam matematika dan menghubungkan antara konsep matematika dengan kehidupan sehari-hari yaitu masing-masing sebesar 83,64\% dan 63,34\% dengan masing-masing kualifikasi sangat baik dan cukup. Pada subjek $\mathrm{S}_{\mathrm{B}} / \mathrm{S}_{05}$ dan $\mathrm{S}_{\mathrm{B}} / \mathrm{S}_{08}$, dari kedua indikator kemampuan koneksi matematik ada satu indikator tergolong kategori sangat baik yaitu pada kemampuan menghubungkan antara konsep dalam matematika. Sedangkan, satu indikator lainnya tergolong pada kategori cukup yaitu pada kemampuan menghubungkan antara konsep matematika dengan kehidupan sehari-hari. Hal ini sesuai dengan hasil penelitian yang dilakukan oleh Anandita (2015) bahwa siswa yang mempunyai kemampuan koneksi matematik baik dapat mengerjakan semua butir soal walaupun terdapat beberapa kesalahan dan dapat memenuhi sebagian indikator koneksi matematik.

\subsection{Kemampuan Koneksi Matematik Siswa Berkemampuan Cukup}

Hasil belajar pada setiap subjek berbeda-beda, hal ini dilihat juga dari hasil analisis tes kemampuan koneksi matematik yang telah dikerjakan oleh masing-masing subjek pada masing-masing indikator kemampuan koneksi matematik secara tertulis. Hal tersebut ditunjukkan dari persentase hasil pekerjaan siswa dan skor rata-rata siswa pada indikator menghubungkan antara konsep dalam matematika dan menghubungkan antara konsep matematika dengan kehidupan sehari-hari yaitu masing-masing sebesar 63,64\% dan 64,44\% dengan masing-masing kualifikasi cukup. Pada subjek $\mathrm{S}_{c} / \mathrm{S}_{02}$, dari kedua indikator kemampuan koneksi matematik, ada satu indikator tergolong kategori baik yaitu pada kemampuan menghubungkan antara konsep dalam matematika. Sedangkan, satu indikator lainnya tergolong dalam kategori kurang yaitu pada kemampuan menghubungkan antara konsep matematika dengan kehidupan seharihari. Pada subjek $\mathrm{S}_{\mathrm{c}} / \mathrm{S}_{08}$, dari kedua indikator kemampuan koneksi matematik ada satu indikator tergolong kategori sangat baik yaitu pada kemampuan menghubungkan antara konsep matematika dengan kehidupan sehari-hari. Sedangkan, satu indikator lainnya tergolong dalam kategori kurang yaitu pada kemampuan menghubungkan antara konsep dalam matematika. Hal ini sesuai dengan hasil penelitian yang dilakukan oleh Anandita (2015) bahwa siswa yang mempunyai kemampuan koneksi matematik cukup dapat mengerjakan semua butir soal tetapi masih terdapat banyak kesalahan dan hanya dapat memenuhi satu indikator koneksi matematik.

\subsection{Kemampuan Koneksi Matematik Siswa Berkemampuan Kurang Baik}

Hasil belajar pada setiap subjek berbeda-beda, hal ini dilihat juga dari hasil analisis tes kemampuan koneksi matematik yang telah dikerjakan oleh masing-masing subjek pada masing-masing indikator kemampuan koneksi matematik secara tertulis. Hal tersebut ditunjukkan dari persentase hasil pekerjaan siswa pada indikator menghubungkan antara konsep dalam matematika dan menghubungkan antara konsep matematika dengan kehidupan sehari-hari yaitu masing-masing sebesar 63,63\% dan 46,67\% dengan masing-masing kualifikasi cukup dan kurang. Pada subjek $\mathrm{S}_{k} / \mathrm{S}_{01}$ dari kedua indikator kemampuan koneksi matematik ada satu indikator tergolong kategori cukup yaitu pada 
kemampuan menghubungkan antara konsep dalam matematika. Sedangkan, satu indikator lainnya tergolong pada kategori kurang yaitu pada kemampuan menghubungkan antara konsep matematika dengan kehidupan sehari-hari. Hal ini sesuai dengan hasil penelitian yang dilakukan oleh Anandita (2015) bahwa siswa yang mempunyai kemampuan koneksi matematik kurang belum mampu menguasai kedua indikator koneksi matematik tetapi dapat mengerjakan semua butir soal walaupun terdapat kesalahan dalam melaukan penyelesaian masalah.

\subsection{Kemampuan Koneksi Matematik Siswa Berkemampuan Sangat Kurang}

Hasil belajar pada setiap subjek berbeda-beda, hal ini dilihat juga dari hasil analisis tes kemampuan koneksi matematik yang telah dikerjakan oleh masing-masing subjek pada masing-masing indikator kemampuan koneksi matematik secara tertulis. Hal tersebut ditunjukkan dari persentase hasil pekerjaan siswa dan skor rata-rata siswa pada indikator menghubungkan antara konsep dalam matematika dan menghubungkan antara konsep matematika dengan kehidupan sehari-hari yaitu masing-masing sebesar $24,85 \%$ dan $44,45 \%$ dengan masing-masing kualifikasi sangat baik. Pada subjek $\mathrm{S}_{K} / \mathrm{S}_{03}$ dari kedua indikator kemampuan koneksi matematik semua tergolong kategori sangat kurang yaitu pada kemampuan menghubungkan antara konsep dalam matematika dan menghubungkan antara konsep matematika dengan kehidupan sehari-hari. Pada subjek $\mathrm{S}_{K} / \mathrm{S}_{06}$ dan $\mathrm{S}_{\mathrm{K}} / \mathrm{S}_{07}$ dari kedua indikator kemampuan koneksi matematik ada satu indikator tergolong kategori sangat kurang yaitu pada kemampuan menghubungkan antara konsep matematika dengan kehidupan sehari-hari. Sedangkan, satu indikator lainnya tergolong dalam kategori kurang yaitu pada kemampuan menghubungkan antara konsep dalam matematika. Hal ini sesuai dengan hasil penelitian yang dilakukan oleh Anandita (2015) bahwa siswa yang mempunyai kemampuan koneksi matematik sangat kurang tidak dapat mengerjakan semua butir soal dan tidak dapat memenuhi satu indikator koneksi matematik.

\section{SIMPULAN}

Berdasarkan analisis data dan hasil penelitian, dapat disimpulkan:

1) Tingkat kemampuan koneksi siswa kelas VII SMPN 2 Labuapi tahun pelajaran 2020/2021 dalam menyelesaikan soal investigasi pada materi segitiga dan segiempat masih pada kategori cukup yaitu $61,7 \%$.

2) Siswa dengan kemampuan koneksi matematik sangat baik sudah mampu menguasai kedua indikator koneksi matematik, yaitu dapat menghubungkan antara ideide dalam matematika dan menghubungkan antara konsep matematika dengan kehidupan sehari-hari.

3) Siswa dengan kemampuan koneksi matematik baik sudah mampu menguasai indikator pertama karena siswa dapat menghubungkan antara ide-ide dalam matematika. Pada indikator kedua siswa mampu menerapkan ide matematika dalam kehidupan sehari-hari tetapi masih belum tepat.

4) Siswa dengan kemampuan koneksi matematik cukup hanya mampu menguasai salah satu indikator kemampuan koneksi saja, baik itu menghubungkan antara ideide dalam matematika ataupun menghubungkan konsep matematika dengan kehidupan sehari-hari. Sedangkan untuk indikator yang lainnya siswa masih kesulitan dalam menerapkannya. 
5) Siswa dengan kemampuan koneksi matematik kurang belum mampu menguasai kedua indikator koneksi matematik karena siswa belum mampu menghubungkan antara ide-ide dalam matematika dan menghubungkan antara konsep matematika dengan kehidupan sehari-hari. Akan tetapi, siswa dapat melakukan penyelesain masalah walaupun belum tepat.

6) Siswa dengan kemampuan koneksi matematik sangat kurang tidak mampu menguasai kedua indikator koneksi matematik karena siswa tidak dapat memahami bagaimana ide-ide dalam matematika saling berhubungan atau saling mendasari. Siswa juga tidak dapat menerapkan konsep matematika dalam kehidupan seharihari

\section{REFERENSI}

Ahmad, M., \& Nasution, D. P. (2018). Analisis Kualitatif Kemampuan Komunikasi Matematis Siswa Yang Diberi Pembelajaran Matematika Realistik. Jurnal Gantang, 3(2), 83-95. https://doi.org/10.31629/jg.v3i2.471

Arikunto, S. (2013). Dasar-dasar Evaluasi Pendidikan. Bumi Aksara.

Lestari, K. E. (2014). Implementasi Brain-based Learning Untuk Meningkatkan Kemampuan Koneksi dan Kemampuan Berpikir Kritis Serta Motivasi Belajar Siswa SMP. Jurnal Pendidikan Unsika, 2(1), 36-46. https://doi.org/10.1136/thx.43.8.627

Lidinillah, D. A. M. (2009). Investigasi Matematika dalam Pembelajaran Matematika di Sekolah Dasar. Jurnal Pendidikan, 1-13.

NCTM. (2000). Principles and Standards for School Mathematics. In The National Council of Teachers of Mathematics, Inc. The National Council of Teachers of Mathematics, Inc.

Prayitno, S. (2019). Evaluasi Pembelajaran Matematika. Duta Pustaka Ilmu.

Rozak, A. (2012). Pengantar Statistika. Intimedia.

Solihatin, E. (2012). Strategi Pembelajaran PPKN. Bumi Aksara.

Subarinah, S. (2016). Profil proses kognitif siswa SMP dalam investigasi matematik ditinjau dari perbedaan gender. Prosiding Seminar Nasional Pendidikan Matematika Universitas Muhamadiyah Purworejo, 3(1), 15-23.

Subarinah, S., Budayasa, I. K., \& Lukito, A. (2018). Profil Proses Kognitif Siswa SMP Dalam Investigasi Matematik. Jurnal Ilmiah Profesi Pendidikan, 3, 15-23. https://doi.org/10.29303/jipp.Vol3.Iss1.51

Subarinah, S., Hikmah, N., \& Azmi, S. (2020). Analysis of Students' Mathematical Investigation Based on the Variation of Mathematical Abilities. 465(Access 2019), 115-118. https://doi.org/10.2991/assehr.k.200827.030

Suhana, C. (2014). Konsep Strategi Pembelajaran. Refika Aditama. 